\title{
ENTERPRISES COMMUNICATION IN E-ENVIRONMENT: CASE STUDY OF LATVIA AND KAZAKHSTAN
}

\author{
Vita Stige-Skuskovnika, ${ }^{1}$ Inga Milevica, ${ }^{2}$ Olga Civzele, ${ }^{3}$ Armiyash Nurmagambetova ${ }^{4}$
}

\author{
${ }^{1}$ Alberta College, Latvia, vita.stige@gmail.com \\ ${ }^{2}$ Alberta College, Latvia, inga.milevica@gmail.com \\ ${ }^{3}$ Alberta College, Latvia, olga.civzele@inbox.lv \\ ${ }^{4}$ L.N.Gumilyov Eurasian National University, Kazakhstan, arnurcom@gmail.com
}

\begin{abstract}
The performed scientific studies show that proper and skilful use of modern technologies can contribute to significant development of companies. Growth of technologies occurs rapidly, and the electronic environment continuously develops and improves along with it. The electronic environment now already offers companies practically all necessary marketing and communication tools for ensuring company development by creating competitive advantages; nevertheless, not all companies can employ the opportunities rendered by the eenvironment, in order to increase company competitiveness and productivity. (Ščeulovs, Gaile-Sarkane 2014). The aim of the paper is to study and compare the enterprises communication in e-environment in two countries Latvia and Kazakhstan. Study material - 130 enterprises of Latvia, 100 enterprises of Kazakhstan; method survey. The study was conducted within the Erasmus ${ }^{+}$project 'Mobility between programme and partner countries (KA107)'. Using previous researches and scientific studies, as well as survey of enterprises representatives in Latvia and Kazakhstan, in this paper, the authors a) give an overview of the main trends of enterprise communication in e-environment and b) compare the experience of the two countries.
\end{abstract}

Keywords: communication; e-environment; enterprise; Latvia; Kazakhstan

JEL Classification: D83, L32

\section{Introduction}

Mobile phones and communication, the internet, TV and social media development affect the reduction of relationship among people, lifestyle and thinking. Everyday and mutual contact is no longer possible without digital communication. It complements and also changes the natural, individual and group communication, creating a demand for new relationship management. (Lasmane 2012). The Internet promotes small and medium business to achieve high rates, focuses on new sales channels and services and also provides modern models of business. Increase in productivity of the organization is one of the main factors of influence of the Internet which simplifies communication, accelerates and automates many business processes and also reduces transaction expenses. (Sergeeva, Khisamova 2015). Introduction of social technologies has brought business and consumers a number of advantages. The main one is access to information and experts' opinions. In this regard, we want to emphasize the impact of social networks on the reputation and corporate image of companies. One line of text published on a person's private social page can be fatal for the brand. Or, on the contrary, will make the company the most popular and respectable one (Kovalev 2018)

According to a study published by the magazine Forbes, the number of people who want to capture their experience and communicate it to others is increasing - I was there, I liked it and I urge you to go (Arnold 2017). Each of these entries on the social network serves as an advertisement for an event or product. It would be foolish not to use this kind of ad for your business. Social media serves as a platform to not only share what is happening, but also to create your own name as a brand (The Business of Influence 2017). 
The aim of the paper is to study and compare the enterprises' communication in e-environment in two countries - Latvia and Kazakhstan. Research question is: Are social media the leading communication tools of the companies' communication in Latvia and Kazakhstan?

The authors studied the communication between electronic environment of various sectors of Latvian and Kazakhstan enterprises. In total, 130 enterprises of Latvia and 100 enterprises of Kazakhstan participated in the study.

The main results show that companies in Kazakhstan, in comparison to Latvia, are just beginning to use social networks and internet for growth and development of business. Enterprises of Latvia are a few steps ahead and the survey results about the social media part prove that Latvian enterprises are aware of the power of digitalization, but resources are not always sufficient to achieve the goals effectively.

\section{E-communication trends in literature resources}

Currently, the processes of global information and communication technologies are developing rapidly, and in recent years, they have been used in full scale. The main task of communication via the Internet is to find potential partners and provide the means to organize the necessary type of communication with them with the required intensity. Today it is almost impossible to find even a small organization that does not have an official website or does not post any information about goods and services on the Internet. (Medvedeva 2014)

As many authors emphasize that the internet provides the necessary tools, easy operation and exchange of information, and therefore, affects all diverse industries and companies. Ščeulovs and Gaile-Sarkane (2010) continue with the idea that the internet has become a useful tool for selling, buying and distributing goods and services globally in a rapidly growing supply chain. The potential market that the internet provides has little or no restrictions by either geography or time, and therefore, it poses a huge impact on any company considering.

The importance of technology in relation to customers has increased significantly (Rodriguez et al. 2014). This is also evidenced by the data from the European communication monitoring, which reveals an increase in leverage since the year 2007 . Then $11.5 \%$ of respondents noted the importance of social media tools in addressing clients, which increased to 40.5\% in 2011 (Kazaka 2014).

Zhanabekova et al. (2014) highlights that in Kazakhstan new media are actively developing increased possibilities of new information technologies. The new information markets are forming, there are new independent mass media, Internet sites, portals, international and domestic media organizations, blog sphere, and social networks are roughly developing.

In Latvia, there is still talk of use of general social media and commercial communication (Kazaka, 2014) and the efficiency of companies using the tools offered by the web without segmentation. The national public relation professional associations and agency blogs do not, in the majority of cases, distinguish between the specificities of communication in specific industry. There is a rarity in some kinds of research on business specific communications such as supermarkets. (Puce 2016) Is there really no difference? Maybe the industry affects channel selection?

The authors of the paper agree that the social media platform's communication has made it faster and easier. It is enough if you have some technical knowledge to perform relatively advanced activities, such as uploading video files on the internet, creating your own profile and maintaining communication. (Šmite 2011)

As Amnesty International (2017) research indicates, Kazakhstan has the highest level of Internet use in Central Asia, reflecting Kazakhstan's greater wealth and more developed communications infrastructure in comparison to its neighbours. Most people who use social media in Kazakhstan do so to communicate with friends. However, human rights defenders, independent journalists, and other activists also use these sites as important portals for sharing information and ideas with new audiences, whom they might not otherwise reach. 
The authors of this paper agree that the benefits of participation in social networks of business give the possibility to find contacts, evaluate efficiency of interpersonal communication, to evaluate the results of communication and reflexive bound and also to evaluate the expenses of advertising in social networks (Ščeulovs, Gaile-Sarkane 2010).

\section{Methodology}

In order to carry out this research, a survey was conducted using a questionnaire and questions prepared by Alberta College (Latvia) staff members in collaboration with the Eurasian National University of L. N. Gumilyov (Kazakhstan) representatives. The survey was created and conducted electronically in each country.

Respondents were selected by students of the college and the university by different types of enterprises (size, popularity, geographic location, etc.). Selected companies received e-mails with a request to fill out a survey in the link provided. E-mails were also sent to emerging companies, as well as correspondence was created on the social media platform Facebook.

Questions covered such clarifications as: the form of the enterprise, the location, the scope of activities, what Internet resources are used by entrepreneurs to promote business and so on. There was also an application of the method of analysis, systematization, processing of the research results.

In total, 230 companies participated in the study: 130 from Latvia and 100 from Kazakhstan. 130 Latvian companies that participated in the study had the following distribution: 37 of culture/art/entertainment industry, 34 of trade/sale, 26 - education/sports, 19 - advertising/marketing, 7 - production, 3 - information technology, 2 - communication / public relation / media and 2 transport / logistics. The Kazakh companies participating in the survey were: 12 of trade / sale, 11 education / science, 10 - food / services, 10 - culture / art / communication / public relations / media, 9 - agriculture / environmental science, 8 - manufacturing / industrial production, 6 - law, 6 construction / real estate, 5 - advertising / marketing and 24 from other industries.

\section{Results}

In terms of experience, the companies in Latvia and Kazakhstan represented similar groups, but in the Latvian study, the companies show a wider spectrum - from 1 year to those companies that are on the market for more than 21 years. Latvia: the vast majority of respondents divided into similar parts by the age of their company - 32 companies $(24.6 \%)$ were in the market since 1 to 5 years, 32 companies (24.6\%) since 11 to 20 years old. 30 companies (23\%) were 6 to 10 years old, and 31 enterprises $(23.8 \%)$ were already 21 years old and above, and five of the respondents $(3,8 \%)$ were in the market since less than a year. Kazakhstan: the main part of interviewed enterprises (44\%) existed from 1 to 5 years, $19 \%$ of companies were situated in the market since about 6 to 10 years, $17 \%$ were young companies that existed for less than a year.

One of the central issues in the study was the question of whether and how specific the social networks were that were used by the companies. The results of the study showed a completely different scene in the two country studies. Kazakh study showed that $16 \%$ of the companies don't use social networks, while Latvian companies indicate almost $100 \%$ of their companies use social networks. And the companies in Latvia have to keep up and the Facebook community is almost $100 \%$ recognized as the leading communication tool. Twitter, Instagram, Youtube and local Latvian social network Draugiem.lv are also used. All companies mentioned 4 major social networks - Facebook, Twitter, Instagram and YouTube. Latvian study results showed: Facebook - 129 (99.2\%), Twitter - 84 (64.6\%), Instagram - 74 (56.9\%), Youtube - 42 (32.2 \%), Draugiem.lv - 37 (28.4 \%), LinkedIn - 2 $(1.5 \%)$, Vkontakte - $2(1.5 \%)$ and Vimeo, Flickr, Behance, Soundcloud - $1(0.76 \%)$.

In Kazakhstan, while businesses prefer more customary methods of promotion, but social media is gaining popularity there, and given that last year the number of users of social networks in the country has almost doubled, it can be assumed that this trend will intensify (Motorina A. 2014). Kazakh study results showed: most companies (43\%) create their profiles in such social networks as Instagram, 33\% 
don't have any profiles, $17 \%$ of respondents choose Facebook. The lowest popularity was given to Telegram and 2GIS. Representatives of medium and small businesses in Kazakhstan, when choosing a social network to search for new customers and sales, make mistakes that greatly affect the results. Therefore, it is necessary to learn how to use the resources of social networks correctly, to approach professionally and not to ignore the possibilities of social networks for business development.

Another important feature is that Kazakhstanis use social networks to communicate and exchange personal information. In order to know how users interact with the online content and see their actions on the company's page, Analytics and Facebook analytics are used. Latvian companies, according to the results of the research, are also using analytical tools more actively than Kazakh companies. They use Google Analytics and Facebook Insights for the analysis - alone or both together.

Data on information about analytical tools used in Kazakhstan is not available as some of the many social networking platforms, such as Facebook and Twitter, have reliable analytics functions, Google Analytics does not support integration with these platforms. Therefore, when analysing traffic in social networks, it is strongly recommended to use these platforms individually to get a clear idea of why and how users interact with your online content.

It is expected that the Kazakh companies specifically highlighted the specifics of the website's communication and its advantages, while all the companies in Latvia, regardless of the industry, have indicated that contact information and information about goods and services is most relevant to the website. Kazakh study results: Analysis of the survey results showed that 45 survey participants have their own home pages on the Internet, $29 \%$ of respondents are working on the creation, $17 \%$ of those participating in the survey don't use the home page in web-based network. Also $43 \%$ of respondents consider that the most relevant information on the home page is information about goods and services. From the points of view of $25 \%$ of Kazakh study participants, it is important to have current information (news and novelties). Contact information (address, email, phone number) as the most relevant was chosen by $18 \%$ respondents, international cooperation and links to social networks were pointed by $4 \%$ and $3 \%$, respectively.

The benefits of social networking according to the respondents are related to the classic needs of the company in various aspects. Prior to using social media in business, it was necessary to make large financial investments in advertising and visibility. Latvian study results: business visibility (112 participants or $86.1 \%$ ), opportunity to communicate directly with existing and potential customers (92 participants or $70.6 \%$ ), communication in social media significantly reduces advertising costs (49 participants or $37.6 \%$ ), opportunity to reach customers in ways that other channels do not offer (58 participants of $44.6 \%$ ). Figure 1 shows the benefits of social networking according to the respondents.

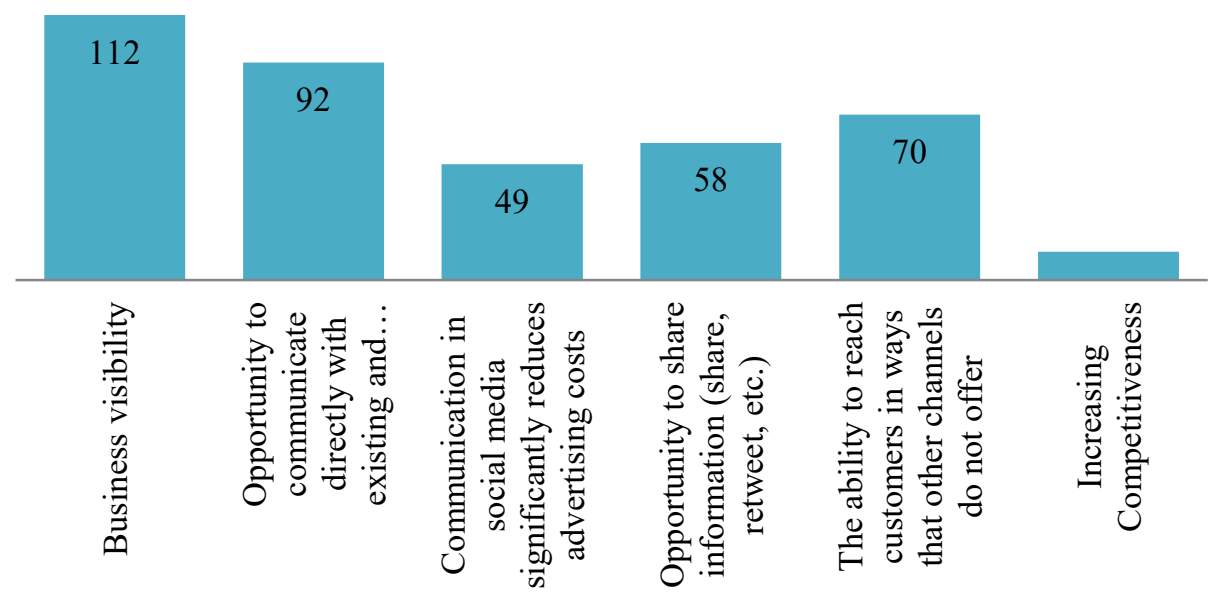

Fig. 1. The benefits of social networking according to respondents of Latvia 
It is interesting to note that the major cultural and artistic companies in Latvia mention the main benefits of digital communication as the opportunity to communicate directly with clients and address them in ways that are not provided by other channels. Websites remain an essential source of contact information and current news, as well as a reference to social networks. Kazakh study results: the creation of recognition (28\%) is the most popular among other options. The variant 'Possibility of direct communication with clients' was chosen by $20 \%$ interviewees. Two options, like 'Communication in social media decreases costs on advertisement' and 'Possibility to share information' gathered 9\%, equally. 'Improving the competitiveness' and 'Possibility to communicate with clients, as it is impossible by other ways' have similar results (6\%). And the lowest number of companies chose 'Possibility to communicate in different foreign languages' (4\%). Other $2 \%$ noted that, it would be nice to have an opportunity to choose needed item and see the prices. Table 1 shows the main benefits of communication of Kazakhstan companies in social networks.

Table 1. The main benefits of communication of Kazakhstan companies in social networks

\begin{tabular}{|l|c|}
\hline Answer options & Number of answers, $\%$ \\
\hline Creation of recognition of the company & 28 \\
\hline Possibility of direct communication with clients & 16 \\
\hline Don't use social networks & 9 \\
\hline Communication in social media decreases costs on advertisement & 9 \\
\hline Possibility to share information (share, repost, retweet, etc.) & 6 \\
\hline Improving the competitiveness & 6 \\
\hline Possibility to communicate with clients, as it is impossible by other ways & 4 \\
\hline Possibility to communicate on different foreign languages & 2 \\
\hline Others & 100 \\
\hline TOTAL & \\
\hline
\end{tabular}

Another aspect of the study was devoted to find out which employees of the enterprise are responsible for communications in social networks. In this aspect, the picture in Latvian and Kazakh companies is quite close: for communication in social networks, the company employs marketing specialists and it is done by the company's heads themselves. Latvian study results: marketing specialist $-38 \%$, head of the company or deputy $-32 \%$, specialist in public relations $-12 \%$, head of social media projects $10 \%$, the secretary/clerk $-4 \%$, agency of communication/media agency (outsourcing) $-2 \%$, others $3 \%$. Kazakh study results: specialist in public relations $-13 \%$, marketing specialist $-22 \%$, head of the company or deputy $-23 \%$, agency of communication/media agency (outsourcing) $-11 \%$, head of social media projects $-9 \%$, the secretary/clerk $-6 \%$, others $-16 \%$.

\section{Conclusions}

The main conclusions of the research are:

1. E-environment offers a lot of many free of charge electronic communication tools and social media platforms, so enterprises can use those communication tools and platforms for different purposes.

2. The most popular e-communication tools between Latvian enterprises are social media platforms, but enterprises of Kazakhstan mostly use home page communication. 
3. Promotion of Kazakhstan business in social circles remains topical, but it is no longer a novelty. The approach of Kazakhstani entrepreneurs to social networks has changed. The structure of use has changed towards the right destination, literate and professional. Thanks to them, communication with a live audience is built. For the Kazakh business, social networks remain an important tool for communication with customers and partners.

4. For many companies, especially not very large, public on the social network even replaces the site. Social networks today are a full-fledged community, where there are rules. To do this, it is not enough just to register a page and actively invite users to visit it.

5. Correctly built social media marketing is the result of following a carefully thought out strategy.

6. In order to build the right communication with customers through social networks, it is necessary to build a promotion strategy. It is necessary to clearly know who the main audience is and to understand the structure of business.

\section{Acknowledgements}

Support for this work was provided by the Erasmus + project 'Mobility between program and partner countries (KA107)'. Also support for this work was provided by the first year students of a study program 'Public Relations' of the Alberta College (Latvia) and the third year students of a study program 'Entrepreneurship' of the Eurasian National University of L. N. Gumilyov (Kazakhstan).

\section{References}

Amnesty International (2017). Think before you post: Closing down social media space in Kazakhstan. London: Amnesty International Ltd. [Accessed 19.04.2018.]. Available from Internet: https://www.amnesty.org/download/Documents/EUR5756442017ENGLISH.pdf

Arnold, A. (2017). 3 Ways The Internet And Social Media Draw Millennials To Live Events [Accessed 19.04.2018.]. Available from Internet: https://www.forbes.com/sites/andrewarnold/2017/12/23/3-ways-theinternet-and-social-media-draw-millennials-to-live-events/\#53d417ad5d8c

Kazaka, O. (2014). Use of social media in corporate communication in Latvia (Sociālo mediju lietošana korporatīvajā komunikācijā Latvijā) (2009-2011). Doctoral Thesis. Rīga: LU Sociālo zinātnuu fakultāte

Kovalev G. (2018) How the micro business develops sales through social networks. Capital. Center of business information. Kapital.kz

Lasmane, S. (2012). Komunikācijas ètika. Rīga: LU Akadēmiskais apgāds

Medvedeva S. (2014) Electronic advertising on the corporate site // KANT. Издательство: ООО Издательство Ставролит.

Motorina A. (2014). Boom in social networks. Expert Kazakhstan, №8 (400)

Puce, R. E. (2016). Analysis of supermarket communications in Social Networks (Lielveikalu komunikācijas sociālajos tìklos analīze). Rìga: Biznesa augstskola Turība

Sergeeva, O. Yu. \& Khisamova, A.S. (2015). The modern Internet industry and its impact on the economy. In The IV International Scientific Conference "Problems of modern economy". Conference proceedings, 74-77.

Ščeulovs, D., \& Gaile-Sarkane, E. (2014). Impact of e-environment on SMEs business development. $19^{\text {th }}$ International Scientific Conference "Economics and Management". Conference proceedings, 409-413.

Ščeulovs, D., \& Gaile-Sarkane, E. (2010). Electronic tools for company's presence, identification and marketing in e-environment: theory and practise. Economics and Management, 15, 775-782. ISSN 1822-6515.

Šmite, R. (2011). Creative Networks (Kreatīvie tīkli). Riga: New Media Culture Centre RIXC

The Business of Influence (2017). Why Do We Share On Social Media? [Accessed 19.04.2018.]. Available from Internet: https://www.forbes.com/video/5612850704001/

Zhanabekova, M., Barlybayeva, S., \& Myssayeva, K. (2014). Development of Mass Media in Kazakhstan. The World Conference on Psychology, Counselling and Guidance, WCPCG-2014, vol. 159, 512-516 